Twenty-ninth Scientific Meeting-Fourteenth Scottish Mmeting

Strathcona House, the Rowett Research Institute,

BucksbURr, Aberdeen, October 20TH, 1945

\title{
THE QUALITY OF PROTEINS
}

\author{
Chairman, Dr. I. LeItcH
}

\section{The Quality of Proteins}

Dr. D. P. Cuthbertson (Rowett Research Institute, Bucksburn, Aberdeen)

It is the amino-acid composition of the proteins in relation to the needs of the organism at the moment which is our main concern, but before I pass to the main topic of our discussion I would remind you that it is the physico-chemical character of the proteins of wheat flour which governs the texture of bread, the caseinogen of milk, its curd, and the coagulative properties of native proteins, the vast array of appetizing egg dishes.

\section{Historical}

The pioneer experiments of Willcock and Hopkins (1906-07) and of Osborne and Mendel (1914) on the effect on growth of proteins lacking certain amino-acids were subsequently brought to a new stage when Rose, one of Mendel's most distinguished pupils, determined the amino-acids indispensable for the growth of the rat. Rose defined an indispensable dietary component as "one which cannot be synthesized by the animal organism, out of the materials ordinarily available at a speed commensurate with the demands for normal growth". Almquist, Jackson, Albanese, Holt, Mitchell and their collaborators have added to this knowledge by studies on animals, including man. As Dr. C. P. Stewart will be dealing in detail with this aspect (Stewart, 1946), I will simply mention that of the amino-acids which Rose (1938) and Rose and Rice (1939) found essential for the normal growth of the rat and dog, namely, valine, methionine, histidine, lysine, tryptophane, phenylalanine, threonine, leucine, isoleucine and arginine, Rose, Haines and Johnson (1942), Rose, Haines, Johnson and Warner (1943) and Albanese, Holt, Frankston, Kajdi, Brumback and Wangerin (1943) have already demonstrated that for men all these, with the exception of histidine, appear to be essential for full functional maintenance. The transamination shuttle mechanism described by Braunstein and Kritzman (1937), and the transmethylation mechanism revealed by Du Vigneaud, Chandler, Cohn and Brown (1940) have gone far to open our eyes to the internal transmutations which may occur and which thus render many of the known amino-acids dispensable in the diet. The tissue protein synthesized during growth on the ten indispensable amino-acids must be assumed to be of a type normal and characteristic of the species, since it is considered axiomatic that "the tissues either form a typical protoplasmic product or none at all" (Osborne and Mendel, 1914). The work of Lee and Lewis (1934) and Louis and Lewis (1944) indicates that the composition of the tissue proteins is not voL. 4,1946$]$ 
apparently altered by changes in the metabolic state induced by inanition and hepatoxic agents. This view is contrary to the observations of Schenck and Wollschitt $(1933,1,2)$ and of Roche $(1934,1,2)$, whose work appears to. indicate a change in the composition of tissue protein either by preferential loss of one or more proteins or through a partial and progressive dislocation of the existing proteins. This aspect of the subject has recently been reviewed by Kosterlitz and Campbell (1945). In parenthesis it may be said that the presence of dietary tyrosine reduces the requirement of phenylalanine, and cystine in a similar fashion that of methionine. Arginine appears to be synthesized slowly but its absence from the diet appears to affect the synthesis of creatine (Bloch and Schoenheimer, 1941). The glycine and glutamic acid requirements of the chick are so high that they become essential amino-acids (Almquist, 1942; Almquist and Grau, 1944; Grau and Almquist, 1944).

Albanese and Irby (1943) have recently brought forward some indirect and not very convincing evidence that the unnatural $(d-)$ forms of certain amino-acids which cannot be utilized may have a toxic effect. Kinsey and Grant (1944) have found no evidence of this in the rat.

\section{The Biological Value of Proteins}

The determination of the "biological value" of protein has been reviewed by Boas-Fixsen (1934-35) and the present writer has elsewhere analysed the earlier literature relating quality of protein to nutritional state (Cuthbertson, 1940, 1944). There are, however, certain points worth emphasizing. During the last world war, and in the years which followed, it became customary to divide dietary proteins into two groups depending on the degree to which the proteins conformed to the then known requirements of man. Thus arose the terms first and second class proteins, and with the main exception of gelatin it became the practice to regard the edible proteins of animal origin as being in the first class category, and those of vegetable origin as second class. These decisions were largely based on a few incomplete analyses of the pure proteins rather than of the mixed proteins of the foodstuff concerned. Nevertheless, this division was useful and served its purpose in drawing attention to the differences in amino-acid composition. It is also of interest that Corry Mann (1935), as the result of careful observations on himself, obtained evidence which suggested that there were marked differences in the biological values of such first class proteins as those of milk and meat, and that the most likely explanation of his results was to be found in the superior nutritive value of milk proteins. Credit for pointing out the supplemental action of the proteins, not only in individual foodstuffs but in the diet as a whole, rests mainly with Mitchell (1924), and this theme has been expanded to a considerable extent by Terroine (1936). It is mainly due to the work and drive of Sir John Orr and his colleagues that the "milk in schools scheme" came into being and set an example to the world of, amongst other things, the practical value of protein supplementation.

An example of protein supplementation within the same seed is the observation of Jones (1944), who found that, although the chief protein of the peanut, arachin, is deficient in methionine and tryptophane, the mixture of it with conarachin in the proportions in which these proteins 
exist in the nut enables young animals to grow at a satisfactory rate. There is also the interesting point that even gelatin may improve a diet in which the sole source of nitrogen is the proteins of wheat flour (Chick and Slack, 1945). When animal protein is short, soya beans, peanuts and cottonseed appear to offer an economical means of supplying dietary protein. The proteins of wheat germ and maize germ are of considerable nutritive value (Stare and Hegsted, 1944). In the light of these and other observations of a similar kind the terms first and second class protein as applied to the mixed proteins in animal and vegetable tissues become meaningless and should be discarded.

\section{Methods for Assessing Quality of Proteins and Factors Influencing the}

Information regarding the amino-acid composition of proteins of foodstuffs is increasing slowly but steadily. It will probably take another five years before completely satisfactory analytical methods have been achieved. At the moment we have to be content with $(a)$ determinations of a few amino-acids with the highest possible accuracy and (b) the "biological value" method for broad surveys of the field of nutritively valuable food proteins. Single food proteins may be found to be good sources of those amino-acids which are most commonly estimated and yet be lacking in one or more of the other essentials for which analytical methods are more difficult, and, often, less accurate. As Block and Bolling (1945) have pointed out, there is one stumbling block in the accurate determination of amino-acids in proteins which must constantly be borne in mind, namely that since the amino-acid methods generally require hydrolysis of the protein before the actual analysis, it is very necessary to determine the susceptibility of each amino-acid to loss during hydrolysis. Not only is the loss different for each amino-acid, but it differs with the conditions of hydrolysis and even more with the presence or absence of other substances in the mixture being hydrolysed. For example, it has been shown that cystine and especially cysteine may be destroyed during acid hydrolysis when carbohydrates are present, but not in their absence. Of the chemical methods available for the determination of amino-acids the isotopic dilution method (Ussing, 1939; Rittenberg and Foster, 1940) is the best. The new microbiological method will require careful study although it would at first sight appear a very promising one.

In the absence of complete analyses of the proteins of many foodstuffs it is still customary to assess their relative biological value by animal experiment involving either growth or nitrogen retention, or alternatively maintenance of bodyweight or nitrogen equilibrium (Boas-Fixsen, 1934-35). During the war much research has been done to determine the relative biological values of different protein-containing foodstuffs so that the most economical use of our protein supplies could be made. As an example of this I would cite the experiments of Chick (1942). Chick found that the advantage of slightly greater digestibility of white flour was more than met by the greater biological value of 85 per cent. extraction or of National Wheatmeal flours in the promotion of the growth of young rats. An interesting point in these experiments was that the more refined the flour the smaller the intake of food. In a five week voL. 4, 1946] 
period the relative amounts consumed by rats in the whole wheat group, the 85 per cent. extraction group and the white flour group were in the ratio of $1 \cdot 3: 1 \cdot 1: 1 \cdot 0$.

In addition to the major differences in amino-acid composition which characterize the proteins, minor differences in the nutritive value of the proteins of a single foodstuff can be induced by certain natural and artificial means. For example, the studies of Everson and Heckert (1944) have demonstrated that the growth promoting qualities of legumes seem to vary with the source, the degree of maturity of the seed and the method of cooking used. These authors found that all of the mature legumes, except peas, were improved in biological value by the heating procedures employed. This general improvement of legumes on cooking was noted also by Everson, Steenbock, Cederquist and Parsons (1944). On the other hand, the proteins of mature peas have a lower biological value after heating.

Recent observations on the effects of severe heat treatment of wheat and oat cereals during processing (Murlin, Nasset and Marsh, 1938; Stewart, Hensley and Peters, 1943) confirm the detrimental effects noted by Morgan (1931) some twelve years earlier.

\section{Intravenous Feeding of Amino-acids}

Henriques and Andersen (1913) demonstrated that a positive nitrogen balance could be achieved in the goat when an enzymic digest of goat's flesh was given to it by vein. Since then numerous experiments on lower animals and man have demonstrated that intravenous feeding with amino-acids can be maintained even for as long as 40 days (see Cuthbertson, 1944, 1945). The technique has obvious possibilities in studying the amino-acid requirements in certain conditions where the ability to ingest, digest or absorb protein is defective.

\section{Amino-acid Composition in Relation to Plasma Protein Formation and Organ Function}

A mixture of the ten purified amino-acids essential for maximum growth in the rat (Rose, 1938), was found by Madden, Carter, Kattus, Miller and Whipple (1943) to be as effective by mouth as most native proteins for the production of plasma protein in standard dogs depleted of plasma. Glycine was generally present in these mixtures to the extent of about 25 per cent. It is interesting to note that, when glycine was omitted, although the nitrogen balance remained positive and the synthesis of plasma protein continued at a satisfactory level, there was a small loss in bodyweight. An attempt to compensate for the glycine omission by increasing the proportion of several of the essential amino-acids in the mixture did not improve the general utilization. Removal of arginine induced a slow fall in plasma protein production. The simultaneous omission for one week of arginine, histidine and most of the lysine caused a marked drop in plasma protein production even although it maintained bodyweight and nitrogen equilibrium. Replacement of methionine by cystine appeared to have no effect on plasma protein production within the period of study. It did, however, lead to a loss of bodyweight and a negative nitrogen balance. The removal of valine or threonine led to a 
negative nitrogen balance and a sharp fall in plasma protein production. These replacement experiments demonstrate the fallacy of placing too much reliance on bodyweight and nitrogen balance data alone, and have a bearing on current methods of determining biological values.

The source, production and utilization of plasma proteins were reviewed by Whipple (1942) and Cuthbertson (1944). It would appear from the work of Whipple and his collaborators that animal protein is twice as effective as vegetable protein in combating oedema and hypoproteinaemia. On the other hand, for albumin production it is apparently unsafe to make sweeping generalizations concerning the group superiority of animal over plant proteins. Certain plant proteins, e.g., rice and potato, appear to favour a low albumin : globulin ratio since they favour the production of globulin.

Hock and Fink $(1943,1,2)$ have recently reported on quality of proteins in relation to dysfunction of liver and kidney. To a basic diet for the young rat containing 1.64 per cent. of cereal protein there was added, as a protein supplement for different groups, fishmeal, skim milk powder, brewer's yeast or wood sugar yeast. In the last two groups growth was only half as fast as in the first two groups, in which growth was good. The addition of 0.2 per cent. of cystine to the last two groups gave growth as good as in the first two. The livers of the rats receiving the yeast supplements had a mottled, spotted appearance and were much enlarged. There was fatty degeneration of the liver with occasional necrosis. The kidneys showed degenerative changes and evidence of glomerulonephritis.

By appropriate modifications of the diet of rats, Himsworth and Glynn $(1944,1,2,1945)$ showed that the development of massive hepatic necrosis (acute yellow, or subacute red, atrophy) with its sequelae, postnecrotic scarring and nodular hyperplasia, depended on the quality and quantity of dietary protein consumed by the animals. Casein in small amounts was effective in preventing the lesion, yeast protein, when it was the sole source of protein, was ineffective even in large amounts. The most obvious difference between these two proteins is that the former is rich, and the latter poor, in methionine, and it has been found that yeast proteins can be made to protect as effectively as casein, when they are enriched by the addition of adequate amounts of methionine.

These authors put forward the hypothesis that massive hepatic necrosis in man may result from an inadequate supply of protein directly or indirectly to the liver. Their results suggest that a high protein diet, or methionine, might prevent sufferers from hepatitis due to poisons or viruses from developing the complication, massive hepatic necrosis.

\section{Amino-acids of Human Milk}

Comparisons of the amino-acids of cow's and woman's milk have been made by Williamson (1944), who found that, apart from tryptophane and methionine, the amino-acids in these milks were roughly in the ratio $2: 1$ in favour of cow's milk. In the case of tryptophane the ratio was $1 \cdot 5: 1$. The $\mathrm{S}$-amino-acids as a group conformed to the general ratio.

\section{Protein Deficiency in Farm Mammals}

In farm mammals protein deficiency is usually manifested by a reduction in growth, fattening, milk production or quantity or quality of the hair. vor. 4,1946$]$ 
For example, Carroll (1934) showed that the use of soya beans in pig feeding led to the production of an inferior quality of pork, and Fowler, Morris and Wright (1934) showed the beneficial effect on milk production of protein concentrates rich in lysine. It is said that, of all farm animals, swine are most likely to suffer from a deficiency of protein from the standpoint of quality and quantity, except when skim milk is available or in regions where peanuts are grown. In ruminants the problem of aminoacid requirement is complicated by synthesis of protein in the paunch (Harris and Mitchell, 1941; Goss, 1943). Pearson and Smith (1943) showed that for ruminants the biological value of a protein may depend not only on its amino-acid content but also on whether its presence in the paunch promotes protein synthesis or hydrolysis.

\section{Protein in Relation to Resistance to Disease}

In the study of the relation of quality of protein to resistance to infection it is not sufficient to determine antibody formation, since that is but one manifestation of the reaction to invasion. It is necessary to determine the tissue reactions as a whole, and the intimate study of these alterations in body substance in relation to infection and disease is one of the most fruitful fields for investigation.

The evidence is fairly conclusive that an antibody is a molecule of globulin, which during synthesis has been specially modified under the influence of antigen. The $\gamma$ globulin fraction is the portion which is particularly related to antibody. The work of Madden and Whipple (1940) has demonstrated that the production of normal serum globulin is dependent upon the utilization of an adequate assortment of aminoacids. Although not yet complete, preliminary analysis of normal serum globulin indicates that it contains all the amino-acids essential for the growing rat.

Cannon, Wissler, Woolridge and Benditt (1944) have recently shown that protein depleted rats have, in addition to a decreased capacity to fabricate antibody, a definitely increased tendency to develop spontaneous infections. These changes are accompanied by a hypo-albuminaemia and hypoglobulinaemia. These authors also reported that there were indications that with high quality proteins hypoglobulinaemic rats quickly regenerated immune globulin, as evidenced by their capacity to reproduce specific antibody. These observations are obviously of great importance in surgery, particularly where the body proteins have been depleted through haemorrhage or exudation or through dietary in. sufficiency during the pre-operative period. Cannon and his collaborators have suggested that in patients whose tissues have been rehydrated, a total serum protein concentration of less than $5 \mathrm{~g}$. per $100 \mathrm{ml}$. of serum implies that pre-operative protein repletion should be attempted.

The experiments of Watson (1937) suggest that the improvement of both quality and quantity of protein in the diet increases resistance of mice to infection by mouth with Salmonella typhi-murium, and to the intraperitoneal injection of a toxic substance isolated from that organism. Rats on a diet contaíning casein are reported by Robertson and Doyle (1936) to have had a higher resistance to Salmonella enteritidis infection than controls fed on vegetable proteins. 


\section{The Effect of Trauma on Protein Metabolism}

It would appear that as a result of physical trauma a phase of vigorous protein catabolism sets in and it has been suggested that this is concerned with the formation of the necessary building stones from which the injured part is repaired, and that particularly in the case of burns the need for amino-acids containing sulphur may dominate the process. The literature has been reviewed by Cuthbertson (1945). The observation by Croft and Peters (1945) that the addition of methionine to the diet of the rat can largely eliminate this catabolic loss of tissue protein is most interesting and now awaits clinical confirmation. It may be that methionine acts in some protective or detoxicating capacity in burned animals. The few human experiments reported so far (Browne, 1945) do not indicate that the nitrogen excretion of burned patients is altered by the addition of this amino-acid to the diet.

It is natural to suppose that for the restoration of damaged muscle a diet high in beef is indicated, and that for the burned patient a diet containing a large amount of plasma protein and skin, if the latter were edible, is required. The processes of protein catabolism and anabolism and of de-amination and re-amination (Braunstein and Kritzman, 1937) which occur during the intermediary phases of amino-acid metabolism, are, however, of such an order that the healing process is, to a considerable extent, independent of the quality and quantity of protein in the diet.

\section{Acceptability of Protein in Relation to Quality}

I would close by referring to reports from observers in Belsen Concentration Camp. Vaughan, Dent and Pitt-Rivers (1945), who worked there following its liberation, found that skim milk was the best vehicle for administering protein to starving subjects but that occasionally it might be necessary to give intact protein by vein in the form of plasma or serum. The unpalatability of protein hydrolysates was a barrier to their acceptance even by the starving subject.

In a personal communication, Captain P. Mollison, R.A.M.C., has described the capriciousness of the appetite of the inmates of Belsen during their convalescence about four weeks after the camp was freed.

Captain Mollison writes: "The truth was that there was enough food in terms of calories but much of it was unpalatable to the patient. Although starving they were extromely particular about their diet and were very difficult to please. . . A Although milk was available as an alternative to the full diet, many of the patients didn't want it and if given it complained that they were not getting enough to support life. Because of their poor appetite, many of them left their food untouched and as thero were no nurses to feed them, their state became rapidly worse."

\section{Summary}

The quality of the protein of the diet is determined by its amino-acid composition and its general physico-chemical characteristics. The requirements of the organism for the amino-acids which it cannot synthesize at all, or only at a rate which is insufficient to meet the local and general requirements at the moment for the building or restitution of tissue protein, and also for certain of its enzymes, hormones, non-protein tissue constituents and metabolites, vary considerably. Not only is it necessary vox. 4, 1946] 
to meet the requirements for the essential amino-acids but it is also necessary to supply sufficient nitrogen, sulphur and specific groupings to meet the local and general anabolic requirements of the body. It should be our ultimate aim to determine the amino-acid requirements of the organism:

(a) During growth, maintenance and eutrophy; (b) during pregnancy and lactation in mammals; (c) after trauma and during wound healing; $(d)$ in relation to resistance to infection and recovery from infection; (e) after exposure to toxic substances of endogenous or exogenous origin; $(f)$ in conditioned deficiencies; $(g)$ in departures from normal hormonal activity; $(h)$ in the bird; $(i)$ in the ruminant; $(j)$ for wool and hide production.

\section{REFERENOES}

Albanese, A. A., Holt, L. E. (Jr.), Frankston, J. E., Kajdi, C. N., Brumback, J. E. (J $\left.\mathrm{J}^{\circ}.\right)$ and Wangerin, D. M. (1943). Proc. Soc. exp. Biol., N.Y., 52, 209. Albanese, A. A. and Irby, V. (1943). Science, 98, 286.

Almquist, H. J. (1942). Fed. Proc. 1, 269.

Almquist, H. J. and Grau, C. R. (1944). J. Nutrit. 28, 325.

Bloch, K. and Schoenheimer, R. (1941). J. biol. Chem. 138, 167.

Block, R. J. and Bolling, D. (1945). The Amino-acid Composition of Proteins and Foods. Springfield, Illinois, U.S.A.: Thomas.

Boas-Fixsen, M. A. (1934-35). Nutr. Abstr. Rev. 4, 447.

Braunstein, A. E. and Kritzman, M. G. (1937). Nature, Lond., 140, 503.

Browne, J. S. L. (1945). Personal communication.

Cannon, P. R., Wissler, R. W., Woolridge, R. L. and Benditt, E. P. (1944). Ann. Surg. 120, 514.

Carroll, W. E. (1934). Circ. Ill. agric. Exp. Sta. no. 369.

Chick, H. (1942). Lancet, 242, 405.

Chick, H. and Slack, E. B. (1945). Biochem. J. 39, xxii.

Croft, P. B. and Peters, R. A. (1945). Lancet, 248, 266.

Cuthbertson, D, P. (1940). Nutr. Abstr. Rev. 10, 1.

Cuthbertson, D. P. (1944). Brit. med. Bull. 2, 207.

Cuthbertson, D. P. (1945). Brit. med. Bull. 3, 96.

Du Vigneaud, V., Chandler, J. P., Cohn, M. and Brown, G. B. (1940). J. biol. Chem. 134, 787 .

Everson, G. J. and Heckert, A. (1944). J. Amer. diet. Ass. $20,81$.

Everson, G. J., Steenbock, H., Cederquist, D. C. and Parsons, H. T. (1944). J. Nutrit. 27, 225.

Fowler, A. B., Morris, S. and Wright, N. C. (1934). Scot. J. Agric. 17, 261.

Goss, H. (1943). Nutr. Abstr. Rev. 12, 531.

Grau, C. R. and Almquist, H. J. (1944). J. Nutrit. 28, 263.

Harris, L. E. and Mitchell, H. H. (1941). J. Nutrit. 22, 183.

Henriques, V. and Andersen, A. C. (1913). Hoppe-Seyl. Z. 88, 357.

Himsworth, H. P. and Glynn, L. E. (1944, 1). Clin. Sci. 5, 93.

Himsworth, H. P. and Glynn, L. E. (1944, 2), Clin. Sci. 5, 133.

Himsworth, H. P. and Glynn, L. E. (1945). Proc. R. Soc. Med. 38, 101.

Hock, A. and Fink, H. (1943, I). Hoppe-Seyl. Z. 278, 136.

Hock, A. and Fink, H. (1943, 2). Hoppe-Seyl. Z. 279, 187.

Jones, D. B. (1944). Fed. Proc. 3, 116.

Kinsey, V. E. and Grant, W. M. (1944). Science, 99, 303.

Kosterlitz, H. W. and Campbell, R. M. (1945). Nutr. Abstr. Rev. $15,1$.

Lee, W. C. and Lewis, H. B. (1934). J. biol. Chem. 107, 649 .

Louis, L. and Lewis, H. B. (1944). J. biol. Chem. 153,381.

Madden, S. C., Carter, J. R., Kattus, A. A. (Jr.), Miller, L. L. and Whipple, G. H. (1943). J. exp. Med. 77, 277.

Madden, S. C. and Whipple, G. H. (1940). Physiol. Rev. 20, 194.

Mann, H. C. C. (1935). Lancet, 228, 145.

Mitchell, H. H. (1924). Physiol. Rev. 4, 424.

Morgan, A. F. (1931). J. biol. Chem. 90, 771.

Murlin, J. R., Nasset, E. S. and Marsh, M. (1938). J. Nutrit. 16, 249. 
Osborne, T. B. and Mendel, L. B. (1914). J. biol. Chem. 17, 325.

Pearson, R. M. and Smith, J. A. B. (1943). Biochem. J. 37, 153.

Rittenberg, D. and Foster, G. L. (1940). J. biol. Chem. 133, 737.

Robertson, E. C. and Doyle, M. E. (1936). Proc. Soc. exp. Biol., N. Y., 35, 374.

Roche, A. (1934, 1). Bull. Soc. Chim. biol., Paris, 16, 270.

Roche, A. (1934, 2). Skand. Arch. Physiol. 69, 75.

Rose, W. C. (1938). Physiol. Rev. 18, 109.

Rose, W. C., Haines, W. J. and Johnson, J. E. (1942). J. biol. Chem. 146, 683.

Rose, W. C., Haines, W. J., Johnson, J. E. and Warner, D. T. (1943). J. biol. Chem. 148, 457.

Rose, W. C. and Rice, E. E. (1939). Science, 90, 186.

Schenck, E. G. and Wollsehitt, H. (1933, 1). Arch. exp. Path. Pharmak. 170, 151.

Schenck, E. G. and Wollschitt, H. (1933, 2) Arch. exp. Path. Pharmak. 173, 219.

Stare, F. J. and Hegsted, D. M. (1944). Fed. Proc. 3, 120.

Stewart, C. P. (1946). Proc. Nutr. Soc. 4, 225.

Stewart, R. A., Hensley, G. W. and Peters, F. N. (1943). J. Nutrit. 26, 519.

Terroine, E. F. (1936). Quart. Bull. Hlth Org. L.o.N. 5, 427.

Ussing, H. H. (1939). Nature, Lond., 144, 977.

Vaughan, J., Dent, C. and Pitt-Rivers, R. (1945). Proc. R. Soc. Med. 38, 395.

Watson, M. (1937). J. Hyg., Camb., 37, 420.

Whipple, G. H. (1942). Amer. J. med. Sci. 203, 477.

Willcock, E. G. and Hopkins, F. G. (1906-07). J. Physiol. 35, 88.

Williamson, M. B. (1944). J. biol. Chem. 156, 47.

\section{The Essential Amino-acids}

\section{Dr. C. P. Stewart (Clinical Laboratory, Royal Infirmary, Edinburgh)}

The proteins present in animal tissues are built up from some twentysix amino-acids, and, inasmuch as the animal can grow only by building more of its various proteins, or maintain itself by making good its continuous protein loss, all these amino-acids may be regarded as essential. By common consent, however, the term essential amino-acid is restricted to those which the animal cannot synthesize from ammonia or some similar source of nitrogen and non-nitrogenous substances derived from fat, carbohydrate, or other amino-acids. Largely because of the experimental methods which have been employed to identify these substances, many authors restrict the term still further to the amino-acids which the animal cannot synthesize in sufficient quantity to promote normal growth. The essential amino-acids are, therefore, indispensable dietary constituents and, in that respect, differ from the vitamins chiefly in being normally ingested in the form of proteins instead of as free chemical entities.

\section{Identification of the Amino-acids Essential to the Growing Rat}

The first clear demonstration that an amino-acid can be an indispensable component of the food was given by Willcock and Hopkins (1906-07). They showed that the protein zein "has no power whatever of maintaining growth in the young animal' but that addition of tryptophane to a diet in which zein was the sole protein diminished the loss of weight and prolonged life though it was unable to allow growth. Zein is deficient in both lysine and tryptophane, and it was later shown by Osborne and Mendel (1914) that addition of these two amino-acids to the zein diet fed to young rats was followed by growth, though neither alone was effective. It was not necessary to add the free amino-acids, equally good results being obtained by adding a protein rich in tryptophane and lysine. These experiments showed, beyond doubt, that both tryptophane voL. 4,1946$]$ 